\title{
Avaliação da técnica de PCR em tempo real no diagnóstico da infecção pelo HTLV-I
}

\section{Evaluation of real time PCR technique in diagnosis of infection to HTLV-I}

Bruna C. Arruda

Orientadores:

Yara M. Gomes

Wayner V Souza

\section{Resumo}

Os vírus linfotrópicos de células T humanas do tipo I (HTLVI) e do tipo II (HTLV-II) são retrovírus humanos que causam destruição e/ou transformação nos linfócitos T. A transmissão ocorre através de relações sexuais, transfusões sangüíneas e produtos hemoderivados, agulhas e seringas contaminadas, da mãe infectada para seu filho, especialmente através do aleitamento materno. No Brasil, cerca de 750.000 pessoas sobrevivem com o vírus. O diagnóstico da infecção pelo HTLV-I/II é feito, habitualmente, com testes sorológicos, baseados na pesquisa de anticorpos contra antígenos do vírus presentes no soro do indivíduo infectado. Como os genomas provirais do HTLV-I e HTLV-II exibem grande homologia, há uma expressiva sororeatividade cruzada. Assim, em muitos casos, a detecção de anticorpos anti-HTLV-I/II embora caracterize a infecção viral, não permite que se estabeleça a distinção entre ambos os agentes. Os testes moleculares empregados para o diagnóstico dos vírus HTLV-I/II, baseiam-se na pesquisa de seqüências genômicas provirais permitindo, com isso, o diagnóstico da infecção antes do aparecimento de qualquer sinal ou sintoma. A carga proviral de HTLV em indivíduos infectados pode ser determinada através da utilização da PCR em tempo real, uma técnica mais rápida e com menor risco de contaminação que a PCR simples ou nested PCR. Para isso, 63 amostras, sendo 33 amostras de indivíduos com sorologia reagente para HTLV e 30 amostras de doadores de sangue da Fundação Hemope foram analisadas para identificação do tipo viral (I ou II) e determinação da carga proviral. A sensibilidade da PCR qualitativa, para identificação do tipo viral, em relação à sorologia (ELISA), foi de 87,9\% (IC 95\%: 70,1 - 95,0\%) e a especificidade foi de 100\% (IC 95\%: 85,9 - 100,0\%). Já a sensibilidade e especificidade da PCR em tempo real foram de 100\% (IC 95\%:
86,7 - 100,0\%) e 96,67\% (IC 95\%: 80,9 - 99,8\%), respectivamente. A carga proviral dos indivíduos reagentes na sorologia variou entre 13 cópias $/ 10^{6}$ células PBMC e 343820 cópias $/ 10^{6}$ células PBMC. Nosso estudo também observou que os indivíduos com PET/MAH tiveram carga proviral mais elevada que a dos indivíduos assintomáticos. A utilização da PCR em tempo real na rotina de monitoramento clínico dos indivíduos infectados permitirá um papel relevante na identificação do vírus e na determinação simultânea da carga proviral, contribuindo para direcionar um tratamento adequado.

Palavras-chave: Vírus linfotrópicos de células T humanas; diagnóstico; PCR em tempo real; carga proviral.

\section{Abstract}

The human lymphotropic T cell virus type I (HTLV-I) or type II (HTLV-II) are human retrovirus that cause the destruction or transformation of the $\mathrm{T}$ lymphocytes. Its transmission occurs through sexual intercourse, blood and hemocomponents transfusions, contaminated needles and syringes, from mother to child, especially through breast feeding. In Brazil, 750000 people live with the infection. The diagnosis of the HTLV-I-II infection is usually done by serologic tests based on the detection of antibodies against viral antigens in the infected serum. Since the proviral genomes of the HTLV-I and HTLV-II have great homology, there is an expressive cross reactivity. Therefore, in many cases, although the detection of HTLV antibodies characterizes the viral infection, it does not allow the establishment of the viral type. Molecular tests used to diagnose the HTLV-I/II viruses are based on the search of the proviral genomic sequences, and allow the diagnoses of the infection before the appearance of any sign or symptom. The HTLV proviral load in infected individuals can be determined through real time PCR, a faster and less contaminating method than the simple PCR or the nested PCR. We analyzed 63 samples, from the Fundação Hemope, which 33 were samples from HTLV seropositive individuals and 30 samples from blood donors, to determine the viral type and the proviral load. The qualitative PCR sensitivity in comparison to the

Dissertação apresentada ao programa de Pós-Graduação em Saúde Pública do Centro de Pesquisas Aggeu Magalhães (CPqAM), da Fundação Oswaldo Cruz (Fiocruz), para obtenção do título de Mestre em Ciências, área de Concentração Saúde Pública.

Correspondência: Bruna C. Arruda

Departamento de Imunologia, Centro de Pesquisas Aggeu Magalhães - CPqAM / Fiocruz

Av. Moraes Rego, $\mathrm{s} / \mathrm{n}$ - Cidade Universitária

50670-420 - Recife-PE - Brasil

E-mail:yara@cpqam.fiocruz.br 
serologic test (ELISA) was 87,9\% (IC 95\%: 70,1 - 95,0\%) and the specificity 100\% (IC 95\%: 85,9 - 100,0\%). The real time PCR sensitivity and specificity in comparison to the serologic test (ELISA) was 100\% (IC 95\%: 86,7 - 100,0\%) e 96,67\% (IC 95\%: 80,9 - 99,8\%) respectively. The seropositive individuals proviral load ranged from 13 to 343.820 copies $/ 10^{6}$ PBMC cells. Our study also observed that individuals with TSP/HAM had higher proviral load than those asymptomatic ones. The use of real time PCR in the clinical routine tests of the infected individuals will have a relevant role in the identification of the virus type and the determination of the proviral load, allowing an adequate treatment.

Key words: Human lymphotropic T cell virus; diagnosis; Real time PCR; viral load.

Avaliação: A Revista Brasileira de Hematologia e Hemoterapia publica os resumos e abstracts de teses da área apresentados em entidades que tenham programas de pós-graduação reconhecidos pelo MEC/Capes e considera a obtenção do título suficiente para sua publicação na forma como se propõe a seção.

Recebido: 09/05/2007

Aceito: 25/09/2007 